\title{
Submission Unit Receipt Date
}

National Cancer Institute

\section{Source}

National Cancer Institute. Submission Unit Receipt Date. NCI Thesaurus. Code C94166.

The date (and time) on which the submission unit is received by the regulatory authority. 